О. Р. Боярчук, І. Б. Чорномидз, Т. М. Косовська, Е. І. Бурбела

ДВНЗ “Тернопільський державний медичний університет

імені І. Я. Горбачевського МОЗ України”

\title{
ОСОБЛИВОСТІ ВИКЛАДАННЯ ПРЕДМЕТА “ОСНОВИ РАЦІОНАЛЬНОГО ХАРЧУВАННЯ” НА КАФЕДРІ ДИТЯЧИХ ХВОРОБ 3 ДИТЯЧОЮ ХІРУРГІЄЮ
}

\author{
O. R. Boyarchuk, I. B. Chornomydz, T. M. Kosovska, E. I. Burbela \\ I. Horbachevsky Ternopil State Medical University \\ PECULIARITIES OF TEACHING THE SUBJECT "BASICS OF RATIONAL \\ NUTRITION” AT THE DEPARTMENT OF PEDIATRIC DISEASES WITH \\ PEDIATRIC SURGERY
}

\begin{abstract}
Мета роботи - проаналізувати основні фактори, що визначають важливість вивчення студентами предмета “Основи раціонального харчування”, визначити методи та засоби навчання, направлені на поліпшення викладання предмета, які застосовуються на кафедрі дитячих хвороб з дитячою хірургією Тернопільського державного медичного університету імені І. Я. Горбачевського.

Основна частина. Враховуючи, що харчування $є$ важливим чинником не лише здоров’я людини, а й визначальним фактором у програмі лікування практично усіх захворювань, вивчення предмета “Основи раціонального харчування” є важливим для майбутнього медичного фахівця практично будь-якої спеціальності. Для забезпечення покращення медичної освіти виникає необхідність вдосконалювати викладання навчального матеріалу студентам-медикам на кафедрах вищих навчальних закладів.

Навчальні програми виділяють обмежену кількість годин для оволодіння дисципліною “Основи раціонального харчування”, тому викладачі проводять постійний пошук сучасних методів викладання дисципліни, які сприятимуть покращенню засвоєння теоретичного і практичного матеріалу. Основна увага під час проведення занять, окрім обговорення теми, розв’язування ситуаційних задач, дискусій та складання меню, приділяється більшому контакту студентів із пацієнтами. Це дає можливість розширити комунікативні здібності студентів, на практиці засвоїти особливості збирання харчового анамнезу, під наглядом викладача складати меню та давати рекомендації із раціонального та лікувального харчування пацієнтам різних вікових категорій із певними захворюваннями. Це дає можливість розширити компетентності майбутніх спеціалістів та покращити підготовку майбутніх спеціалістів зі спеціальності “Здоров’я людини”.
\end{abstract}

Висновок. Підвищення зацікавлення студентів-медиків у вивченні дисципліни “Основи раціонального харчування” поліпшить якість надання медичної допомоги пацієнтам у майбутньому.

Ключові слова: основи раціонального харчування; нутриціологія; методика викладання.

The aim of the work - to analyze the main factors determining the importance of students studying the subject "Basics of rational nutrition”, to identify methods and means of training aimed at improving teaching of the subject, which are used at the Department of Children's Diseases with Pediatric Surgery, I. Horbachevsky Ternopil State Medical University.

The main body. Taking into account that nutrition is an important factor not only in human health, but also a determining factor in the treatment program for virtually all diseases, the study of the subject "Basics of rational nutrition" is important for the future medical specialist of practically any specialty. To ensure the improvement of medical education, there is a need to improve the teaching of scientific materials to medical students at the departments of higher education.

The curriculum allocates a limited number of hours for mastering the discipline "Basics of rational nutrition", which is why teachers conduct a constant search for modern methods of teaching discipline that will help improve the mastery of theoretical and practical material. The main focus during the classes, in addition to discussing the topic, solving situational problems, discussions and drawing up the menu, is given to the greater contact of students with patients. It enables to broaden the students' communicative abilities, in practice, to master the peculiarities of the collection of food history, under the supervision of a teacher to compile a menu and to give recommendations for rational and therapeutic nutrition for patients of different age groups with certain diseases. This provides an opportunity to expand the competence of future specialists and improve the training of future specialists in the field of "Human Health".

Conclusion. Increasing the interest of medical students in studying the discipline "Basics of rational nutrition" will improve the quality of providing medical care to patients in the future.

Key words: basics of rational nutrition; nutritiology; teaching methods.

() О. Р. Боярчук, І. Б. Чорномидз, Т. М. Косовська, Е. І. Бурбела 
Вступ. Харчування - один із найвагоміших чинників здоров'я дітей. Існує цілком обгрунтована наукова думка, що при раціональному харчуванні тривалість людського життя може досягати 120 150 років [3]. Їжа забезпечує організм енергією, необхідною для пересування і трудової діяльності, служить джерелом “пластичних” речовин, білків, жирів і вуглеводів, а також вітамінів і мінеральних солей, завдяки яким відбувається оновлення клітин і тканин, вироблення гормонів, ферментів та інших регуляторів обмінних процесів в організмі також відбувається завдяки харчовим продуктам. Від характеру і повноцінності харчування залежить обмін речовин в організмі, функціонування органів та систем, тканин і клітин. При правильному харчуванні забезпечується повноцінне функціонування імунної системи, підвищується опірність організму, його можливість протистояти хворобам [3].

Від адекватного забезпечення життєво необхідними харчовими інгредієнтами залежать такі важливі характеристики дитячого організму, як гармонічність фізичного і психічного розвитку, обмін речовин, стан імунної системи, захворюваність $[8,11]$. Академік О. Ф. Тур писав з цього приводу: “Правильне харчування $є$ суттєвим моментом в житті дитини і разом з тим одним з найважливіших факторів у системі суспільних та індивідуальних профілактичних заходів, які зберігають здоров'я і життя дітей” [6]. У наші дні харчування дітей шкільного віку характеризується зниженням споживання найбільш цінних у біологічному відношенні харчових продуктів, таких, як м'ясо і м'ясопродукти, молоко і молочні продукти, риба і рибні продукти, яйця, олія, фрукти й овочі. Разом з тим, істотно збільшується споживання хліба і хлібопродуктів, а також картоплі. Нині в Україні, внаслідок нераціонального харчування, 3 \% дітей мають дефіцит маси тіла, а $15 \%$ - відставання росту [6, 7].

Найважливішим чинником росту та розвитку дитячого організму $є$ адекватне харчування дітей першого року життя [4, 12]. За даними офіційної статистики, з тими чи іншими порушеннями харчування пов'язано 35 \% хвороб дітей віком $<5$ років. За оцінками ВООЗ, у всьому світі $30 \%$ (186 млн) дітей віком <5 років відстають у зрості, 18 \% (115 млн) мають низьке співвідношення маси тіла до зросту внаслідок неналежного годування чи повторних інфекцій, у той час як 43 млн мають надмірну масу тіла $[4,12]$. У багатьох країнах лише 30 \% дітей віком 6-23 міс., які перебувають на грудному вигодовуванні, одержують прикорм, який відповідає належним для їх віку критеріям дієтичної різноманітності й частоти годування [4].

Враховуючи важливість харчування дитини в ранньому віці, в Україні набуває актуальності розвиток концепції “Харчування нового життя 1000 днів”, відповідно до якої харчування дитини від зачаття і протягом перших двох років життя має вирішальне значення для іï росту та розвитку і забезпечує довготривалий вплив протягом усього подальшого життя [4, 5, 12].

Майбутньому лікарю в сучасних умовах необхідно вміти аналізувати середовище, в якому перебуває пацієнт, та виокремлювати фактори, що впливають на його здоров'я. Одним із таких факторів $€$ харчування [2]. Нутриціологія (від лат. Nutritio харчування та грец. Logos - вчення) - це наука про їжу і харчування, про продукти харчування, про харчові речовини й інші компоненти, що містяться в цих продуктах, про їх дію і взаємодії, про їх споживання, засвоєння, витрачання й виведення з організму, про їх роль у підтримці здоров'я або виникненні захворювань [9, 10]. Дитяча нутриціологія - невід'ємна, хоча і специфічна частина загальної науки про харчування, i її вихідні принципи базуються на фундаментальних уявленнях про фізіологічні потреби людини в енергії та харчових речовинах. Останнім часом наші уявлення про ці потреби істотно змінилися. Значно розширився перелік харчових речовин, віднесених до життєво необхідних, сформовано уявлення про важливу роль про- і пребіотиків, мікроелементів та інших компонентів їжі у забезпеченні нормальної життєдіяльності людини [8].

Не менш важливим $є$ використання їжі як компонента лікувальної програми при багатьох захворюваннях дитячого віку. Правильне харчування хворої дитини $є$ однією з основних ланок у загальному комплексі терапевтичних заходів. Лікувальне харчування, побудоване з урахуванням патогенезу захворювання, віку дитини, особливостей його розвитку, нормалізує порушені обмінні процеси в організмі, компенсує необхідні енергетичні витрати, поставляючи відповідні харчові компоненти, сприяє підвищенню імунітету, ліквідації патологічного процесу, відновленню здоров’я [10].

Однак при різних захворюваннях роль лікувального харчування неоднозначна. В одних випадках лікувальне харчування $є$ єдиним методом лікування, без якого ніяка інша терапія не дасть бажаного результату. До цієї групи захворювань відносяться вроджені порушення обміну речовин та фермент- 
них систем. В інших випадках лікувальне харчування є одним з основних методів лікування, без якого інші терапевтичні заходи виявляються малоефективними. До цієї групи захворювань відноситься алергійна патологія, у першу чергу харчова алергія, а також ожиріння, цукровий діабет, хронічні захворювання шлунково-кишкового тракту, печінки, нирок тощо. I, нарешті, при ряді патологічних станів лікувальне харчування, не будучи вирішальним фактором у лікуванні хвороби, в основному визначає загальний хід метаболізму, сприяє посиленню захисних реакцій, забезпечуючи тим самим ефективність проведеної терапії. До останньої групи захворювань відноситься патологія серцево-судинної системи, органів дихання, опорно-рухового апарату. Дієтотерапія є одним 3 основних патогенетичних методів лікування практично усіх захворювань [10].

На сучасному етапі надання медичної допомоги особливо важливим для практичного лікаря є володіння навичками, які необхідні для діагностики аліментарних розладів в організмі, метаболічних зрушень, обмінних патологій, вивчення їх причин у зв’язку із зовнішніми факторами, призначення адекватного харчування, що є дієвим чинником комплексної системи первинної, вторинної і третинної профілактики захворювань і їх ускладнень. Важливим є набуття спеціальних фахових знань щодо виявлення причин розвитку та ознак полінутрієнтних дефіцитів, вміння призначити дієтичне лікування з метою подолання означеної проблеми, призначення корегуючих харчових рекомендацій 3 метою поліпшення здоров'я та запобігання розвитку рецидивів [2].

Мета роботи - проаналізувати основні фактори, що визначають важливість вивчення студентами предмета “Основи раціонального харчування”, визначити методи та засоби навчання, направлені на поліпшення викладання предмета, які застосовуються на кафедрі дитячих хвороб з дитячою хірургією Тернопільського державного медичного університету імені І. Я. Горбачевського.

Основна частина. На кафедрі дитячих хвороб 3 дитячою хірургією ДВНЗ “Тернопільський державний медичний університет імені І. Я. Горбачевського МОЗ України” студентам 3 курсу медичного факультету із напрямком підготовки “Здоров’я людини” пропонується елективний курс “Основи раціонального харчування”, метою якого є поглиблення і узагальнення студентами знань про основні харчові продукти, їх енергетичну цінність, режим харчу- вання, визначення особливостей раціонального і лікувального харчування. Предмет складає 90 год, із яких 16 год - лекції, 32 год - практичні заняття та 42 год займає самостійна робота студентів.

Програма дисципліни структурована на три розділи.

- I розділ вивчає функцію та біологічну дію їжі, різновиди харчування і принципи збалансованого харчування, потреби в основних харчових інгредієнтах, характеристику основних продуктів дитячого харчування.

- II розділ вивчає вигодовування дитини першого року життя. Студенти при цьому навчаються збирати харчовий анамнез у дітей та батьків, навчаються правильно складати меню дітям, що перебувають на природному, штучному і змішаному вигодовуванні, вчаться оцінювати добовий раціон немовляти, проводять корекції харчування, оволодівають технікою приготування молочної суміші і годування немовлят $з$ пляшечки і ложечки.

- III розділ вивчає організацію харчування хворої дитини. Студенти навчаються основних принципів лікувального харчування дітей при рахіті, гіпотрофії, залізодефіцитній анемії, ожирінні, лактозній недостатності, целіакії, муковісцидозі, зі спадковими порушеннями, при цукровому діабеті, галактоземії, фенілкетонурії, інфекційних захворюваннях, хронічних захворюваннях органів травлення, синдромі мальабсорбції, захворюваннях сечовивідної системи, серцево-судинній патології.

Видами навчальних занять згідно з навчальним планом є: лекції, практичні заняття, самостійна робота студентів. Лекції охоплюють основний теоретичний матеріал окремої або кількох тем навчальної дисципліни, розкривають основні проблемні питання відповідних розділів дисципліни. Практичні заняття передбачають детальний розгляд студентами окремих теоретичних положень навчальної дисципліни з викладачем і формування вміння та навичок їх практичного застосування шляхом індивідуального виконання студентом сформульованих завдань та вирішення ситуаційних задач. Під керівництвом викладача студенти вивчають особливості збору харчового анамнезу у здорових дітей та при різних захворюваннях. Розраховують індивідуальні потреби організму в основних нутрієнтах в нормі та при хронічних патологічних станах. Під керівництвом викладача студенти вивчають різновиди харчування і принципи збалансованого харчування. Складають меню окремому пацієнту, розв’ язують ситуаційні задачі. При цьому 
кожен із студентів має змогу відчути себе практичним лікарем, який дає рекомендації хворим. Згодом разом із викладачем студенти обговорюють раціони та обирають найбільш оптимальний. У разі помилки обговорюються можливі наслідки надлишку або недостачі певного продукту в обраного пацієнта. У результаті проведеного заняття студенти швидше засвоюють матеріал та усвідомлюють повною мірою важливість ретельно підібраного раціону та можливі шкідливі наслідки у випадку нераціонального харчування $[1,2]$.

Самостійна робота студентів передбачає оволодіння студентом навчальним матеріалом, а саме самостійне опрацювання окремих тем навчальної дисципліни у час, вільний від обов'язкових навчальних занять, а також передбачає підготовку до усіх видів контролю.

У результаті вивчення дисципліни “Основи раціонального харчування” студент повинен оволодіти навичками: організації харчування здорових дітей першого року життя та раннього віку, а також харчування хворих дітей, збирання харчового анамнезу у здорових дітей та при різних захворюваннях, розрахунку індивідуальних потреб організму в основних нутрієнтах в нормі та при хронічних патологічних станах, складання одноденного меню дитині (оцінити значення білків, жирів, вуглеводів у дитячому харчуванні).

Висновки. 1. Після закінчення елективного курсу з “Основ раціонального харчування” на кафедрі

\section{Список літератури}

1. Бомба М. Я. Здорове харчування як стратегічний ресурс національної безпеки України / М. Я. Бомба, Л. Я. Івашків // Вісн. НАН України. - 2013. - № 6. С. 32-41.

2. Зозуляк Н. В. Особливості викладання курсу за вибором “Нутриціологія” на кафедрі пропедевтики внутрішньої медицини / Н. В. Зозуляк // Буковинський медичний вісник. - 2015. - Т. 19, № 4 (76). - С. 241-242.

3. Лазаренко К. П. Значення наукових розробок 3 основ харчування здорової та хворої людини у підготовці майбутніх лікарів / К. П. Лазаренко, І. М. Чеховська, Н. В. Білера // Сучасний стан та перспективи підготовки лікарів-інтернів у Харківському національному медичному університеті : матеріали 42-ї наук.-метод. конф. з інтернатури, Харків, 26 квітня 2016 р. - Харків, 2016. - С. 71-74.

4. Харчування дітей раннього віку: теорія і практика / [С. Няньковський, Д. Добрянський, Ю. Марушко та ін.] - Львів : Ліга-Прес, 2009. - 288 с. дитячих хвороб з дитячою хірургією студент здатен повною мірою оцінити харчовий статус людини: він може розрахувати енерговитрати здорової та хворої дитини і, відповідно, необхідну для нього калорійність харчування, його потребу в певних вітамінах, мікроелементах та біологічно активних добавках. Студенти здатні визначити, які продукти харчування є рекомендованими, а які є надзвичайно шкідливими у здорових дітей та при певних патологічних станах.

2. Під час вивчення дисципліни студент має можливість оволодіти як основними загальними, так і спеціальними компетентностями, які необхідні майбутньому фахівцеві. Студент стає здатним здійснювати індивідуальний підхід до кожного окремого пацієнта та, діючи за певним алгоритмом, ухвалювати обгрунтоване рішення і давати дієві рекомендації. При вивченні предмета “Основи раціонального харчування” стає зрозумілим, що у багатьох випадках саме раціональний режим харчування здатен запобігти розвитку багатьох захворювань та значно пришвидшити процес одужання хворих. Слід також відмітити, що робота із пацієнтами, розв'язання тематичних ситуаційних задач у команді та обговорення із викладачем усіх допущених помилок та можливих негативних наслідків для здоров’я під час заняття сприяє тому, що отримана інформація засвоюється набагато швидше та на триваліший період часу.

5. Щодо впровадження концепції “Харчування нового життя. 1000 днів” в Україні / С. Л. Няньковський, О. Г. Шадрін, Т. К. Знаменська [та ін.] // Здоровье ребенка. - 2014. - № 5 (56). - С. 73-77.

6. Нутриціологія : навч. посіб. / за ред. Н. В. Дуденко. Х. : Світ книг, 2013. - 560 с.

7. Проданчук М. Г. До проблеми безпеки харчування населення України / М. Г. Проданчук, В. Л. Корецький, Н. М. Орлова // Проблеми харчування. - 2005. - № 2. C. 7-10.

8. Смоляр В. І. Сучасні проблеми дитячої нутриціології / В. І. Смоляр // Проблеми харчування. - 2007. - № 3 [Електронний ресурс]. - Режим доступу : http://medved. kiev.ua/arh_nutr/nt3_2007.htm.

9. Теоретичні та практичні аспекти нутриціології: навч. посіб. / Л. В. Андріюк, Т. П. Гарник, В. М. Яцюк, С. І. Федяєва. - Львів : Посвіт, 2016. - 126 с.

10. Дитяча нутриціологія : навч. посіб. / Г. М. Траверсе, О. Г. Шадрін, В. К. Козакевич, О. В. Горішна. - Полтава, 2009. - 175 с. 
11. Тутельян М. А. Научные основы разработки принципов питания здорового и больного ребенка / М. А. Тутельян, И. Я. Конь // Вопросы детской диетологии. 2005. - T. 3, № 3. - С. 5-8.

\section{References}

1. Bomba, M.Ia., \& Ivashkiv, L.Ia. (2013). Zdorove kharchuvannia yak stratehichnyi resurs natsionalnoi bezpeky Ukrainy [Healthy food as a strategic resource of national safety of Ukraine]. Visnyk NAN Ukrainy - Journal of NAS of Ukraine, 6, 32-41 [in Ukrainian].

2. Zozuliak, N.V. (2015). Osoblyvosti vykladannia kursu za vyborom "Nutrytsiolohiia” na kafedri propedevtyky vnutrishnoi medytsyny [Features of teaching the elective course "Nutritiology" at the propedeutics of internal medicine department]. Bukovynskyi medychnyi visnyk Bukovyna Medical Journal, 4 (76), 241-242 [in Ukrainian].

3. Lazarenko, K.P., Chekhovska, I.M., \& Bilera, N.V. (2016). Znachennia naukovykh rozrobok z osnov kharchuvannia zdorovoi ta khvoroi liudyny u pidhotovtsi maibutnikh likariv [Significance of scientific developments on the basis of nutrition of a healthy and sick person in the preparation of future physicians]. Suchasnyi stan ta perspektyvy pidhotovky likariv-interniv u Kharkivskomu natsionalnomu medychnomu universyteti: materialy 42-i naukovo-metodychnoi konferentsii z internatury. Kharkiv : KhNMU [in Ukrainian].

4. Niankovskyi, S., Dobrianskyi, D., \& Marushko, Iu. (2009). Kharchuvannia ditei rannoho viku: teoriia i praktyka [Nutrition for early childhood: theory and practice]. Lviv: Liha-Pres [in Ukrainian].

5. Niankovskyi, S.L., Shadryn, O.H., Znamenska, T.K., Beketova, H.V., Ivakhnenko, O.S., \& Yatsula, M.S. (2014). Shchodo vprovadzhennia kontseptsii "Kharchuvannia novoho zhyttia. 1000 dniv" v Ukraini [Concerning the implementation of the concept "Feeding a new life. 1000 days" in Ukraine]. Zdorove rebenka - Health of a Child, 5 (56), 73-77 [in Ukrainian].
12. Шадрін О. Г. Проблемні питання харчування дітей раннього віку та шляхи їх вирішення / О. Г. Шадрін, Г. А. Гайдучик // Український медичний журнал. - 2016. № 2 (112) [Електронний ресурс]. - Режим доступу : http:// www.umj.com.ua/article/magazine/112.

6. Dudenko, N.V. (2013). Nutrytsiolohiia: navchalnyi posibnyk [Nutritionology: a tutorial]. Kharkiv, Svit knyh [in Ukrainian].

7. Prodanchuk, M.H., Koretskyi, V.L., \& Orlova, N.M. (2005). Do problemy bezpeky kharchuvannia naselennia Ukrainy [To the problem of food security of the population of Ukraine]. Problemy kharchuvannia-Problems of Nutrition, 2, 7-10 [in Ukrainian]

8. Smoliar, V.I. (2007). Suchasni problemy dytiachoi nutrytsiolohii [Modern problems of child nutritiology]. Problemy kharchuvannia - Problems of Nutrition, 3 [in Ukrainian].

9. Andriiuk, L.V., Harnyk, T.P., Yatsiuk, V.M., \& Fediaieva, S.I. (2016). Teoretychni ta praktychni aspekty nutrytsiolohii [Theoretical and practical aspects of nutritionology]. Lviv : Posvit [in Ukrainian].

10. Traverse, H.M., Shadrin, O.H., Kozakevych, V.K., \& Horishna, O.V. (2009) Dytiacha nutritsiolohiia. Navchalnyi posibnyk [Children's Nutritionology. Textbook]. Poltava [in Ukrainian].

11. Tutelyan, M.A., \& Kon, I.Ya. (2005). Nauchnye osnovy razrabotki printsipov pitaniya zdorovogo i bolnogo rebenka [Scientific foundations for the development of the principles of nutrition of a healthy and sick child]. Voprosy detskoy dietologii - Questions of Children's Dietology, 3, 5-8 [in Russian].

12. Shadrin, O.H., \& Haiduchyk, H.A. (2016). Problemni pytannia kharchuvannia ditei rannoho viku ta shliakhy yikh vyrishennia [Problematic nutrition issues for young children and ways to solve them]. Ukrainskyi medychnyi zhurnalUkrainian Medical Journal, 2 (112) [in Ukrainian]. 